\title{
TANGGUNG JAWAB HUKUM PENYIDIK KEPOLISIAN TERHADAP BARANG BUKTI YANG KURANG LENGKAP
}

\author{
Oleh: \\ Ni Made Trisna Dewi ${ }^{1}$ \\ E-mail : madetrisnadewishmh@gmail.com \\ Dosen Fakultas Hukum, Universitas Dwijendra
}

\begin{abstract}
Examination of cases before the trial, as well as in the preliminary examination, there are many problems related to evidence. Although evidence has an important role in a criminal case, it is not that the presence of evidence is absolutely necessary in a criminal case. Where the judge in making a decision does not always rely on evidence because it only happens case by case, or it can be said that not all cases can be resolved just because of the evidence. The formulation of the problem raised in this study is what is the legal basis for the police against incomplete evidence and what is the legal responsibility of the police for incomplete evidence. This type of research is empirical legal research. This research uses an approach that examines the prevailing laws and regulations, legal theory, and can be in the form of scholars' opinions related to problems in this scientific paper, namely the legal responsibility of the police for incomplete evidence. The conclusion of this research is that the legal basis of the police for incomplete evidence is Article 110 paragraph (2) and (3) and Article 138 paragraph (2) of the Criminal Procedure Code where the Public Prosecutor returns the case file to the investigator to complete the case file concerned. In returning the case file, the Public Prosecutor is also required to provide instructions regarding the incompleteness of the case file, both regarding the completeness of the case file clearly and clearly so that it can be understood by the Investigator.
\end{abstract}

Keywords: Responsibility, police, incomplete evidence

\begin{abstract}
Abstrak
Pemeriksaan perkara di muka persidangan, maupun dalam pemeriksaan pendahuluan banyak masalah yang menyangkut barang bukti. Meskipun barang bukti mempunyai peranan penting dalam suatu perkara pidana, bukanlah bahwa kehadiran barang bukti itu mutlak selalu ada dalam perkara pidana. Dimana hakim didalam menjatuhkan putusannya tidak selalu berpatokan pada barang bukti karena itu hanya terjadi kasus per kasus, atau bisa dikatakan tidak semua kasus bisa diselesaikan hanya karena adanya barang bukti tersebut. Rumusan masalah yang diangkat dalam penelitian ini adalah bagaimanakah dasar hukum kepolisian terhadap barang bukti yang kurang lengkap dan bagaimanakah tanggung jawab hukum kepolisian terhadap barang bukti yang kurang lengkap. Jenis penelitian ini adalah penelitian hukum emperis Penelitian ini menggunakan pendekatan yang mengkaji peraturan perundang-undangan yang berlaku, teori hukum, dan dapat berupa pendapat para sarjana yang terkait dengan permasalahan dalam tulisan ilmiah ini adalah tanggung jawab hukum kepolisian terhadap barang bukti kurang lengkap. Kesimpulan dari penelitian ini adalah dasar hukum kepolisian terhadap barang bukti yang kurang lengkap adalah Pasal 110 ayat (2) dan (3) dan Pasal 138 ayat (2) KUHAP dimana Penuntut Umum mengembalikan lagi berkas perkara
\end{abstract}


tersebut kepada Penyidik untuk melengkapi berkas perkara yang bersangkutan. Dalam pengembalian berkas perkara tersebut Penuntut Umum juga diwajibkan memberikan petunjuk-petunjuk tentang kekuranglengkapan berkas perkara tersebut baik mengenai kelengkapan formil maupun kelengkapan materiil dengan jelas sehingga dapat dipahami oleh Penyidik

Kata Kunci: Tanggung jawab, kepolisian, barang bukti kurang lengkap.

\section{PENDAHULUAN}

Peranan barang bukti dalam pemeriksaan perkara pidana adalah penting dan relevan untuk evaluasi terhadap pelaksanaan KUHAP, selain dari alat bukti sebagaimana yang dimaksud dalam Pasal 184 KUHAP ada hal lain yang penting bagi pembuktian atau sebagai bukti untuk mengejar kebenaran yakni barang bukti:

1. Hakim ketua memperlihatkan kepada terdakwa segala barang bukti dan menanyakan kepadanya apakah ia mengenal benda itu dengan memperhatikan ketentuan sebagaimana dimaksud dalam Pasal 45 Undang-undang ini.

2. Jika perlu benda diperlihatkan juga oleh Hakim ketua sidang kepada saksi.

3. Apabila dianggap perlu untuk membuktikan Hakim ketua sidang membacakan atau memperlihatkan surat atau berita acara kepada terdakwa atau saksi dan selanjutnya minta keterangan seperlunya tentang hal itu.

Pemeriksaan perkara di muka persidangan, maupun dalam pemeriksaan pendahuluan banyak masalah yang menyangkut barang bukti. Istilah barang bukti yang dalam Wetbook van Straf Recht, maupun dalam Undang-undang lainnya peninggalan penjajahan Belanda tidak dapat ditemukan. Dalam dunia peradilan di Indonesia telah timbul istilah barang bukti yang dipergunakan untuk menunjuk barang-barang yang disita. Dimana tujuan dari penyitaan adalah tidak lain untuk kepentingan pembuktian terutama ditujukan sebagai barang bukti dimuka persidangan. Kemungkinan besar tanpa barang bukti, perkara tidak akan dapat diajukan kepersidangan. Oleh karena itu agar perkara tadi lengkap dengan barang bukti, penyidik melakukan penggeledahan berikut penyitaan terhadap barang bukti tersebut, yang akan dipergunakan sebagai bukti dalam penyidikan, penuntutan dan pemeriksaan dimuka sidang.

Meskipun barang bukti mempunyai peranan penting dalam suatu perkara pidana, bukanlah bahwa kehadiran barang bukti itu mutlak selalu ada dalam perkara pidana. Dimana hakim didalam menjatuhkan putusannya tidak selalu berpatokan pada barang bukti karena itu hanya terjadi kasus per kasus, atau bisa dikatakan tidak semua kasus bisa diselesaikan' hanya karena adanya barang bukti tersebut. Karena untuk memperoleh keyakinan hakim atas kesalahan terdakwa, harus ada kesesuaian antara barang bukti dengan alat bukti tersebut seperti yang tersebut dalam Pasal 184 ayat 1 (KUHAP) maka disinilah letak pentingnya barang bukti tersebut. Oleh sebab itu penulis mengangkat judul skripsi Tanggung Jawab Hukum Kepolisian Terhadap Barang Bukti Kurang Lengkap

Berdasarkan latar belakang permasalahan yang diuraikan diatas, 
maka penulis merumuskan permasalahan sebagai berikut :

1. Bagaimanakah dasar hukum kepolisian terhadap barang bukti yang kurang lengkap ?

2. Bagaimanakah tanggung jawab hukum kepolisian terhadap barang bukti yang kurang lengkap ?

Barang bukti adalah apa-apa yang menjadi tanda sesuatu perbuatan kejahatan dan sebagainya (Koesparmono Irsan, 2007 : 90)Barang bukti adalah benda atau barang yang digunakan untuk meyakinkan Hakim akan kesalahan Terdakwa terhadap perkara pidana yang dituntutkan kepadanya (Sudarsono, 2007 : 47). Barang bukti adalah benda yang digunakan untuk meyakinkan Hakim akan kesalahan terdakwa terhadap perkara pidana yang dituduhkan kepadanya; barang yang dapat dijadikan sebagai bukti dalam suatu perkara (Tim Redaksi Kamus Besar Bahasa Indonesia, 2012 : 140). Barang bukti adalah hasil serangkaian tindakan Penyidik dalam penyitaan dan atau penggeledahan dan atau pemeriksaan surat untuk mengambil alih dan atau menyimpan dibawah penguasaannya benda bergerak atau tidak berwujud untuk kepentingan pembuktian dalam penyidikan, penuntutan dan peradilan

Istilah barang bukti dalam perkara pidana yaitu barang mengenai mana delik dilakukan (obyek delik) dan barang dengan mana delik dilakukan yaitu alat yang dipakai untuk melakukan delik misalnya pisau yang dipakai untuk menikam orang. Termasuk juga barang bukti ialah hasil dari delik, misalnya uang Negara yang dipakai (korupsi) untuk membeli rumah pribadi,maka rumah pribadi itu merupakan barang bukti, atau hasil delik (Andi Hamzah, 2009 : 100).Tetapi, walaupun istilah barang bukti disebutkan dalam sejumlah pasal KUHAP, dan dalam putusan pengadilan harus selalu ditetapkan dengan tegas tentang apa yang akan dilakukan terhadap barang bukti, namun dalam pasal-pasal KUHAP tidak ada yang menegaskan tentang kedudukan dari suatu barang bukti. Berbeda halnya dengan alat bukti, yang secara tegas disebutkan dalam pasal tentang sistem pembuktian, yaitu Pasal 183 KUHAP, di mana ditentukan bahwa Hakim tidak boleh menjatuhkan pidana kepada seorang kecuali apabila dengan sekurang-kurangnya dua alat bukti yang sah ia memperoleh keyakinan bahwa suatu tindak pidana benar-benar terjadi dan bahwa terdakwalah yang bersalah melakukannya.

Menurut Pasal 194 ayat (1) KUHAP, apabila suatu tindak pidana terbukti, maka terhadap barang bukti dari hasil kejahatan dikembalikan kepada yang berhak menerima kembali yang namanya tercantum (saksi korban) tanpa syarat apapun dalam putusan tersebut, kecuali menurut Undang-Undang harus dirampas untuk kepentingan Negara atau dimusnahkan, atau dirusak, sehingga tidak dapat dipergunakan.

Alat-alat bukti yang sah, oleh Pasal 184 ayat (1) KUHAP, hanya dibatasi pada:

a. keterangan saksi;

b. keterangan ahli;

c. surat;

d. petunjuk;

e. keterangan terdakwa.

Ketentuan dalam pasal-pasal KUHAP tentang kedudukan suatu barang bukti, dapat muncul kesan bahwa pembentuk KUHAP memandang barang bukti sebagai suatu tambahan semata-mata terhadap alat-alat bukti yang sah. Dengan kata lain, barang bukti itu 
sendiri bukan merupakan suatu alat bukti, melainkan merupakan bukti tambahan belaka terhadap alat-alat bukti yang sah menurut KUHAP, yaitu sebagai bukti tambahan terhadap alat bukti keterangan saksi, keterangan ahli, surat, petunjuk, dan keterangan terdakwa. Selanjutnya dalam Pasal 197 ayat (2) KUHAP ditentukan bahwa tidak dipenuhinya ketentuan dalam ayat (1) huruf a, b, c, d, e, f, h, j, k dan I pasal ini mengakibatkan putusan batal demi hukum. Dalam Pasal 197 ayat (1) KUHAP tercantum pada huruf d bahwa sebagai salah satu hal yang harus dimuat dalam putusan pemidanaan adalah pertimbangan yang disusun secara ringkas mengenai fakta dan keadaan beserta alat pembuktian yang diperoleh dari pemeriksaan di sidang yang menjadi dasar penentuan kesalahan terdakwa. Menurut ketentuan dalam Pasal 197 ayat (2) KUHAP, pokok ini merupakan salah satu pokok yang akan mengakibatkan putusan batal demi hukum jika tidak dimuat dalam putusan pemidanaan yang bersangkutan. Istilah yang digunakan dalam Pasal 197 ayat (1) huruf d KUHAP tersebut adalah istilah "alat pembuktian".

Pasal lainnya di mana juga ada digunakan istilah "alat pembuktian", yaitu Pasal 82 ayat (3) huruf d KUHAP yang mengatur mengenai Praperadilan. Pada Pasal 82 ayat (3) huruf $b$ KUHAP tersebut ditentukan bahwa, dalam hal putusan menetapkan bahwa benda yang disita ada yang tidak termasuk alat pembuktian, maka dalam putusan dicantumkan bahwa benda tersebut harus segera dikembalikan kepada tersangka atau dan siapa benda itu disita. Dari rumusan Pasal 82 ayat (3) huruf $b$ KUHAP ini jelas bahwa selain benda yang disita tetapi yang tidak termasuk alat pembuktian, ada juga benda yang disita yang termasuk alat pembuktian. Jadi, dari pasal tersebut dapat diketahui bahwa penggunaan istilah alat pembuktian mencakup juga benda yang disita. Sekalipun dalam pasal ini yang digunakan adalah istilah "benda yang disita", bukan istilah "barang bukti", tetapi jelas bahwa yang dimaksudkan dengan "benda yang disita" itu adalah apa yang dalam hukum acara pidana dinamakan "barang bukti". Konsekuensinya, pengertian "alat pembuktian" dalam Pasal 197 ayat (1) KUHAP, juga mencakup semua yang dapat dijadikan bukti, yaitu meliputi baik alat bukti maupun barang bukti.

Barang bukti itu sangat penting bagi Hakim untuk mencari dan menemukan kebenaran materiil atas perkara yang sedang ia tangani atau periksa. Barang bukti dan alat bukti merupakan suatu rangkaian yang tidak dapat dipisahkan. Dalam persidangan, untuk mengejar kebenaran apa yang didakwakan Jaksa Penuntut Umum maka setelah memeriksa Terdakwa dan Saksi, Hakim pun memperlihatkan barang bukti tersebut, dan menanyakan kepada Terdakwa dan Saksi apakah ia mengenal barang bukti tersebut, dan apakah betul barang bukti tersebut yang dicuri oleh Terdakwa dan apakah benar barang bukti itu adalah milik Saksi, dan seterusnya

Pasal 184 ayat (1) apabila dikaitkan dengan Pasal 181 ayat (3) KUHAP, maka barang bukti akan menjadi :

a. Keterangan saksi, jika keterangan tentang barang bukti dimintakan kepada Saksi.

b. Keterangan terdakwa, jika keterangan tentang barangbukti diminta kepada Terdakwa

c. Keterangan ahli, jika seorang ahli memberikan keterangan secara 
lisan terkait dengan barang bukti di sidang pengadilan.

d. Petunjuk, barang bukti pengganti merupakan petunjuk bagi Hakim untuk menyatakan Terdakwa bersalah melakukan tindak pidana, apabila ada korelasi dengan barang bukti atau dengan barang bukti yang lain.

e. Surat, jika seorang ahli memberikan keterangan secara tertulis di luar persidangan terkait dengan barang bukti yang dimintakan keterangan kepadanya (Lilik Mulyadi, 2012 : 76)

Barang bukti memiliki peranan penting dalam mendukung upaya bukti dalam persidangan, sekaligus memperkuat dakwaan Jaksa Penuntut Umum terhadap tindak pidana yang dilakukan oleh Terdakwa, serta dapat membentuk dan menguatkan keyakinan hakim atas kesalahan Terdakwa. Itulah sebabnya Jaksa Penuntut Umum semaksimal mungkin harus mengupayakan atau menghadapkan barang bukti selengkap-lengkapnya di sidang pengadilan.

\section{METODE}

Penelitian ini dilakukan dengan menggunakan metode penelitian emperis dengan sifat penelitian deskriptif kualitatif, dengan sumber data yang terdiri dari sumber data primer, sumber data sekunder, menggunakan teknik pengumpulan data dengan menggunakan wawancara, dan untuk menganalisa data yang telah dikumpulkan maka dipergunakan beberapa teknik, yaitu teknik deskripsi, kualitatif.

Sumber data dari penelitian hukum emperis diperoleh melalui sumber data primer, yaitu dengan cara mengadakan penelitian langsung ke lapangan terkait dengan permasalahan yang diangkat. Sumber data sekunder, yaitu data yang penulis peroleh berasal dari kepustakaan, Teknik pengumpulan data dalam penelitian ini dilakukan dengan menggunakan wawancara dengan pihak-pihak atau orang-orang yang terkait baik secara langsung atau tidak terhadap penelitian ini. teknik pengumpulan data dilakukan dengan teknik kepustakaan, yaitu dengan membaca literatur yang berhubungan dengan permasalahan penelitian, menggunakan Kitab Undang-undang Hukum Pidana, Kitab Undang-Undang Hukum Acara Pidana, UndangUndang No. 2 Tahun 2002 Tentang Kepolisian Negara Republik Indonesia serta dilakukan dengan cara menginventarisir, mempelajari dan mendalami bahan-bahan hukum yang relevan dengan obyek penelitian. Kemudian dilakukan pengklasifikasian bahan-bahan yang sejenis, mencatat dan mengolahnya secara sistematis sesuai dengan tujuan penelitian.

Untuk menganalisa data yang telah dikumpulkan maka dipergunakan beberapa teknik analisis yaitu: Teknik deskripsi, dengan menggunakan teknik ini peneliti menguraikan secara apa adanya terhadap suatu kondisi atau posisi dan proposisi-proposisi hukum atau non-hukum. Teknik interpretasi berupa penggunaan jenisjenis penafsiran dalam ilmu hukum seperti analogi dan penafsiran gramatikal. Teknik evaluasi merupakan penilaian berupa tepat atau tidak tepat, setuju atau tidak setuju, benar atau salah peneliti terhadap suatu pernyataan rumusan norma, keputusan, baik yang tertera dalam data primer maupun dalam data sekunder. Teknik argumentasi berupa pernyataan- pernyataan yang berasal dari pemikiran atau analisis penulis yang dituangkan dalam bentuk tulisan. 


\section{PEMBAHASAN}

\section{Teori Penegakan Hukum}

Ketika berbicara Penegakan hukum, maka harus dipahami lebih dahulu adalah apa yang dimaksud dengan penegakan hukum dan faktor yang mempengaruhi untuk menganalisisnya. Dalam konstelasi negara modern, hukum dapat difungsikan sebagai sarana rekayasa sosial (law as a tool of social engineering) (Roscoe Pound, 2009:7).

Penegakan hukum adalah usaha melaksanakan hukum sebagaimana mestinya, mengawasi pelaksanaannya agar tidak terjadi pelanggaran, dan jika terjadi pelanggaran ada usaha lain untuk memulihkan hukum yang dilanggar itu agar ditegakkan kembali (Muhammad Abdulkadir, 2006:115).

Penegakan hukum yang mempunyai nilai yang baik adalah menyangkut penyerasian antara nilai dengan kaidah serta dengan perilaku nyata manusia. Pada hakikatnya, hukum mempunyai kepentingan untuk menjamin kehidupan sosial masyarakat, karena hukum dan masyarakat terdapat suatu interelasi (Sunarto Siswanto, 2004:71).

\section{Konsep Penyidikan}

Penyidikan untuk pertama kalinya dipergunakan sebagai istilah yuridis dalam Undang-Undang Nomor 13 Tahun1961 tentang KetentuanKetentuan Pokok Kepolisian Negara Republik Indonesia. Dalam hal ini penyidik kepolisian diberi wewenang untuk melakukan suatu penyidikan dalam suatu peristiwa pidana baik dalam mengungkap fakta-fakta dan bukti-bukti yang ada serta dalam menemukan tersangka pelaku tindak pidana. Teori ini menekankan pada kesesuaian rangkaian proses peradilan pidana Indonesia yang berlaku saat ini agar tidak terjadi hal- hal diluar langkah peraturan-peraturan yang berlaku (M. Fauzy RA, 2019:1).

Barang bukti tidak diatur didalam Pasal 183 KUHAP atau didalam pasal tersendiri didalam KUHAP sebagai salah satu syarat dalam pembuktian namun barang bukti mempunyai nilai/fungsi dan bermanfaat dalam upaya pembuktian, walaupun barang bukti yang disita oleh petugas penyidik tersebut secara yuridis formal juga bukan sebagai alat bukti yang sah menurut KUHAP. Akan tetapi, dalam praktik peradilan, barang bukti tersebut ternyata dapat memberikan keterangan yang berfungsi sebagai tambahan dalam pembuktian.

Pengembalian Berita Acara Pemeriksaan yang tidak memenuhi ketentuan dalam undang-undang, merupakan bagian dari proses menciptakan perlindungan terhadap tersangka dari sikap sewenangwenang penyidik dalam membuat Berita Acara Pemeriksaan yang tidak lengkap tersebut. Barang bukti itu sangat penting bagi Hakim untuk mencari dan menemukan kebenaran materiil atas perkara yang sedang ia tangani atau periksa. Barang bukti dan alat bukti merupakan suatu rangkaian yang tidak dapat dipisahkan. Dalam persidangan, untuk mengejar kebenaran apa yang didakwakan Jaksa Penuntut Umum maka setelah memeriksa Terdakwa dan Saksi, Hakim pun memperlihatkan barang bukti tersebut, dan menanyakan kepada Terdakwa dan Saksi apakah ia mengenal barang bukti tersebut, dan apakah betul barang bukti tersebut yang dicuri oleh Terdakwa dan apakah benar barang bukti itu adalah milik Saksi, dan seterusnya (Momo Kelana, 2012 : 64). Pasal 184 ayat (1) apabila dikaitkan dengan Pasal 181 ayat (3) KUHAP, maka barang bukti akan menjadi : 
a. Keterangan saksi, jika keterangan tentang barang bukti dimintakan kepada Saksi.

b. Keterangan terdakwa, jika keterangan tentang barang bukti diminta kepada Terdakwa

c. Keterangan ahli, jika seorang ahli memberikan keterangan secara lisan terkait dengan barang bukti di sidang pengadilan.

d. Petunjuk, barang bukti pengganti merupakan petunjuk bagi Hakim untuk menyatakan Terdakwa bersalah melakukan tindak pidana, apabila ada korelasi dengan barang bukti atau dengan barang bukti yang lain.

e. Surat, jika seorang ahli memberikan keterangan secara tertulis di luar persidangan terkait dengan barang bukti yang dimintakan keterangan kepadanya.

Barang bukti memiliki peranan penting dalam mendukung upaya bukti dalam persidangan, sekaligus memperkuat dakwaan Jaksa Penuntut Umum terhadap tindak pidana yang dilakukan oleh Terdakwa, serta dapat membentuk dan menguatkan keyakinan hakim atas kesalahan Terdakwa. Itulah sebabnya Jaksa Penuntut Umum semaksimal mungkin harus mengupayakan atau menghadapkan barang bukti selengkap-lengkapnya di sidang pengadilan. Pelaksanaan penelitian terhadap tersangka dan barang bukti tersebut masing-masing dibuatkan berita acaranya, dan ditandatangani oleh penuntut umum dan penyidik yang menyaksikan acara itu (Djoko Prakoso, 2012 : 97). Berita acara serah terima tersangka dan barang sitaan/bukti memuat hal-hal sebagai berikut:

1. Kapan serah terima tersangka dan barang bukti dilakukan;
2. Nama, pangkat, nomor registrasi perkara dan jabatan penyidik/penyidik pembantu yang menyerahkan tersangka dan barang bukti tersebut;

3. Surat pengantar pengiriman tersangka dan barang bukti disertai nomor polisi dan tanggalnya;

4. Nama tersangka sebagaimana terlampir dalam daftar tersangka;

5. Barang bukti sebagaimana terlampir dalam daftar barang bukti;

6. Nama, pekerjaan, pangkat/jabatan penuntut umum pada kejaksaan negeri setempat yang menerima tersangka dan barang bukti;

7. Tempat diserahkan tersangka dan barang bukti;

8. Nama, pekerjaan, pangkat/jabatan dan alamat para saksi (2 orang) yang menyaksikan penyerahan tersebut;

9. Tempat, tanggal ditanda tanganinya berita acara tersebut.

Dengan diserahkannya tersangka dan barang bukti oleh penyidik kepada penuntut umum, maka penyidikan atas perkara tersebut telah selesai dan secara yuridis tanggung jawab atas tersanga dan barang bukti tersebut beralih kepada penuntut umum. Namun demikian bukan berarti tugas penyidik terhadap perkara tersebut selesai dan tidak ada sangkut pautnya dengan proses persidangan. Hubungan koordinasi fungsional dan instansional antara penyidik dan penuntut umum masih berlangsung sampai ke pelaksanaan putusan hakim.

Seperti diketahui bahwa didalam pembuktian tidaklah mungkin dan dapat tercapai kebenaran mutlak (absolut). Bahwa semua pengetahuan kita hanya bersifat relatif, yang didasarkan pada pengalaman, penglihatan, dan pemikiran tentang sesuatu yang selalu tidak pasti benar. 
Jika diharuskan adanya syarat kebenaran mutlak untuk dapat menghukum seseorang, maka sebagian besar dari pelaku tindak pidana tidaklah dapat di hukum, pastilah dapat mengharapkan bebas dari penjatuhan pidana (Djoko Prakoso, 2012 : 98). Satu-satunya yang dapat diisyaratkan dan yang sekarang dilakukan adalah adanya suatu kemungkinan besar bahwa terdakwa telah bersalah melakukan perbuatan-perbuatan yang telah di dakwakan sedangkan ketidaksalahannya walaupun selalu ada kemungkinan merupakan suatu hal yang tidak dapat diterima. Jika hakim atas dasar alat-alat bukti yang selalu yakin bahwa menurut pengalaman dan keadaan telah dapat diterima, bahwa suatu tindak pidana benar-benar telah terjadi dan terdakwalah dalam hal tersebut yang bersalah (guilty), maka terdapatlah bukti yang sempurna, yaitu bukti yang sah dan meyakinkanDan dalam hal pembuktian pidana kita mengenal istilah yang berbunyi : "Tidak dipidana tanpa kesalahan". Dalam bahasa Belanda :"Geen straf zonder schuld" disinilah letak pelunya pembuktian tersebut apakah seseorang benarbenar bersalah menurut apa yang diatur dalam Undang-undang yang ditujukan kepadanya (Djoko Prakoso, 2012 : 99).

Bagian yang paling penting praktek penegakan hukum dalam kegiatan penyidikan adalah mengenai pembuktian yang diatur dalam Kitab Undang-Undang Hukum Acara Pidana karena disini penyidik mengumpulkan bukti untuk membuat terang suatu tindak pidana yang terjadi. Barang bukti merupakan benda sitaan yangperlu dikelola dengan tertib dalam rangka mendukung proses penyidikan tindak pidana.
Banyaknya dokumen atau barang bukti yang ada sering menjadi masalah dalam proses analisa barang bukti. Terkait dengan hal ini, menjadi penting bagi seorang penyelidik untuk mencari barang bukti yang relevan terkait dengan perkara. Harus diingat, bahwa tidak selamanya dokumen yang diperoleh oleh penyidik penting bagi penyelidikan maupun penyidikan.

Dokumen yang diperoleh tersebut seorang penyidik atau penyelidik memiliki 2 ( dua ) sifat yaitu:

1. Dapat menolong proses penyidikan atau penyelidikan sebuah perkara;

2. Dapat menciderai proses penyidikan atau penyelidikan perkara tersebut.

Lebih lanjut lagi Association Certified Fraud Examiner menjelaskan bahwa kedua hal tersebut terjadi tergantung dari bagaimana seorang penyidik atau penyelidik tersebut melakukan analisa maupun mengelola barang bukti yang ada sehingga menjadi alat bukti yang diterima di pengadilan. Perlu diingat bahwa relevansi dari sebuah barang bukti tidak dapat dengan mudah ditentukan diawal penyelidikan, maka untuk itu diperlukan analisa mendalam oleh penyelidik, dengan cara melakukan penyaringan dan menyusun klasifikasi dokumen sebagaimana sudah dijelaskan diatas. Namun yang paling penting bahwa proses analisa tersebut tidak menyebabkan adanya perubahan maupun kerusakan dari dokumen tersebut (Ratna Nurul Afiah, 2011.: 36)

Pengelolaan barang bukti dan analisa barang bukti tersebut akan berhasil apabila seorang penyelidik maupun penyidik yang melakukan analisa dan pengelolaan paham benar mengenai pasal atau perkara yang dipersangkakan, kemudian sudah memiliki konstruksi kasus yang dibuat dari hipotesa maupun data awal, 
dimana konstruksi kasus tersebut dapat selalu di update sesuai dengan fakta yang didapatkan. Konstruksi kasus tersebut juga berguna untuk mengetahui peran masing-masing pihak yang terlibat dalam perkara yang dianalisa serta barang bukti yang mendukung peran orang-orang tersebut.

Praktek terkadang sebuah alat bukti gagal untuk memperkuat perkara yang sedang disidangkan dikarenakan kegagalan penyidik dan penyelidik dalam proses pengambilan dan pengelolaan barang yang akan dijadikan alat bukti di pengadilan. Yang memperburuk keadaan ini adalah terkadang, seorang penyidik merasa cukup puas apabila berkas perkaranya sudah diterima oleh penuntut umum, tanpa mempedulikan kualitas analisa dan pengelolaan barang bukti yang ada. Menjaga kualitas dan admisibilitas barang bukti, meskipun dianggap sepele,sangat penting untuk dilakukan, karena sebagaimana diterangkan diatas, barang bukti memiliki dua sifat yang sangat bertolak belakang, memperkuat perkara, atau bahkan menciderai perkara yang dipersangkakan.

Apabila barang bukti dirasa kurang lengkap kepolisian bertanggungjawab untuk terpenuhinya atau melengkapi barang bukti yang akan dijadikan alat bukti dalam suatu perkara pidana. Untuk melengkapi barang bukti baru bisa dilakukan melalui proses penyidikan dan dengan keterangan tersangka, dan bisa juga dengan pengelolaan barang bukti yang sudah ada yang tetap mengacu pada prinsip-prinsip legalitas, transparan, proporsional, akuntabel, efektif dan efesien. Legalitas artinya prinsip pengelolaan dilaksanakan mengacu pada hukum acara yang berlaku yakni KUHAP, baik dalam rangka proses penyitaannya, maupun menjaga agar barang bukti tersebut tetap terjaga. Barang bukti yang ada harus tetap dipertanggungjawabkan

keberadaannya, pengelolaannya dan penggunaannya dalam rangka penyidikan maupun penyelesaian perkara, dimana dalam hal ini berarti barang bukti tersebut sudah diserahkan kepada Jaksa Penuntut Umum sesuai dengan ketentuan yang berlaku.

Prinsip-prinsip pengelolaan barang bukti dalam Peraturan Kepala kepolisian Negara Republik Indonesia Nomor 10 Tahun 2010 Tentang Tata Cara Pengelolaan barang Bukti Di Lingkungan Kepolisian Negara Republik Indonesiameliputi:

a. legalitas, yaitu setiap pengelolaan barang bukti harus sesuai denganketentuan peraturanperundang-undangan;

b. transparan, yaitu pengelolaan barang bukti dilaksanakan secara terbuka;

c. proporsional, yaitu keterlibatan unsur-unsur dalam pelaksanaan pengelolaan barang bukti harus diarahkan guna menjamin keamanannya;

d. akuntabel, yaitu pengelolaan barang bukti dapat dipertanggungjawabkan secara hukum, terukur, dan jelas; dan

e. efektif dan efisien yaitu setiap pengelolaan barang bukti harus dilakukan dengan mempertimbangkan adanya keseimbangan yang wajar antara hasil dengan upaya dan sarana yang digunakan.

Barang bukti temuan yang telah disita penyidik sebagaimana dimaksud dalam Pasal 7 ayat (2) paling lama $1 \mathrm{x}$ 24 (satu kali dua puluh empat) jam wajib diserahkan kepada Pejabat Pengelola Barang Bukti. Pejabat 
Pengelola Barang Bukti adalah anggota Polri yang mempunyai tugas dan wewenang untukmenerima, menyimpan, mengamankan, merawat, mengeluarkan

dan memusnahkanbenda sitaan dari ruang atau tempat khusus penyimpanan barang bukti.

Pejabat Pengelola Barang Bukti yang menerima penyerahan sebagaimana dimaksud pada ayat (1) wajib melakukan pencatatan ke dalam buku register dan disimpan pada tempat penyimpanan barang bukti.Barang bukti temuan terdiri atas benda yang dapat lekas rusak atau membahayakan, sehingga tidak mungkin untuk disimpan, dapat diambil tindakan sebagaimana diatur dalam Hukum Acara Pidana.Dalam hal barang bukti temuan berupa narkotika jenis tanaman, dalam waktu $1 \times 24$ (satu kali dua puluh empat) jam wajib dimusnahkan sejak saat ditemukan, setelah sebagian disisihkan untuk kepentingan penyidikan, penuntutan, dan pemeriksaan.

\section{PENUTUP}

Dari uraian di atas dapat disimpulkan;

1. Dasar hukum kepolisian terhadap barang bukti yang kurang lengkap adalah Pasal 110 ayat (2) dan (3)dan Pasal 138 ayat (2) KUHAP dimana Penuntut Umum mengembalikan lagi berkas perkara tersebut kepada Penyidik untuk melengkapi berkas perkara yang bersangkutan. Dalam pengembalian berkas perkara tersebut Penuntut Umum juga diwajibkan memberikan petunjuk-petunjuk tentang kekurang lengkapan berkas perkara tersebut baik mengenai kelengkapan formil maupun kelengkapan materiil dengan jelas sehingga dapat dipahami oleh Penyidik.
Pasal 110 KUHAP

Pasal 110 ayat 2, berbunyi :

Dalam hal penuntut umum berpendapat bahwa hasil penyidikan tersebut ternyata masih kurang lengkap, penuntut umum segera mengembalikan berkas perkara itu kepada penyidik disertai petunjuk untuk dilengkapi.

Pasal 110 ayat 3 , berbunyi :

Dalam hal penuntut umum mengembalikan hasil penyidikan untuk dilengkapi, penyidik wajib segera melakukan penyidikan tambahan sesuai dengan petunjuk dari penuntut umum.

Pasal 138 ayat 2, berbunyi :

Dalam hasil penyidikan ternyata belum lengkap, penuntut umum mengembalikan berkas perkara kepada penyidik disertai petunjuk tentang hal yang harus dilakukan untuk dilengkapi dan dalam waktu empat belas hari sejak tanggal penerimaan berkas, penyidik harus sudah menyampaikan kembali berkas perkara itu kepada penuntut umum.

2. Tanggung jawab hukum kepolisian terhadap barang bukti yang kurang lengkap adalah kepolisian bertanggungjawab untuk terpenuhinya atau melengkapi barang bukti yang akan dijadikan alat bukti dalam suatu perkara pidana. Untuk melengkapi barang bukti baru bisa dilakukan melalui proses penyidikan dan dengan keterangan tersangka, dan bisa juga dengan pengelolaan barang bukti yang sudah ada yang tetap mengacu pada prinsip-prinsip legalitas, transparan, proporsional, akuntabel, efektif dan efesien. Dan tanggung jawab penyidik sebagaimana yang tercantum dalam Pasal 138 ayat (2) Dalam hasil penyidikan ternyata belum 
